\title{
PENGARUH MODEL PEMBELAJARAN BERBASIS MASALAH TERHADAP KEMAMPUAN BERPIKIR KRITIS MATEMATIS SISWA SMP NEGERI 62 HALMAHERA SELATAN PADA MATERI KUBUS
}

\author{
${ }^{1}$ Susanti Abdurahman, ${ }^{2}$ Ikram Hamid, ${ }^{3}$ Ariyanti Jalal \\ 1,2,3 Prodi Pendidikan Matematika Universitas Khairun
}

\begin{abstract}
ABSTRAK
Penelitian ini merupakan penelitian eksperimen yang bertujuan untuk mengetahui, (1) Bagaimana kemampuan berpikir kritis matematis siswa setelah diterapkannya model pembelajaran berbasis masalah (2) Apakah model pembelajaran berbasis masalah berpengaruh terhadap kemampuan kerpikir kritis matematis siswa.

Populasi dalam penelitian ini adalah seluruh siswa kelas VIII SMP Negeri 62 Halmahera Selatan yang berjumlah 42 siswa yang kemudian tersebar pada dua kelas dan Sampel yang secara acak di ambil yaitu siswa kelas $\mathrm{VIII}_{1}$ yang berjumlah 20 siswa. Pengumpulan data dilakukan melalui tes kemampuan berpikir kritis matematis siswa dengan 6 butir soal sebagai instrumen yang telah divalidasi oleh validator. Analisis data yang digunakan adalah Kriteria kemampuan berpikir kritis, dan uji t.

Hasil menunjukkan $60 \%$ yang sudah mencapai nilai di atas rata-rata, sehingga dikategorikan sebagai siswa yang sudah berpikir kritis, 40\% siswa mencapai nilai di bawah rata-rata sehingga dikategorikan sebagai siswa yang berpikir kritisnya kurang, Pengujian hipotesis dengan menggunakan uji $\mathrm{t}$, dari hasil perhitungan diperoleh $\mathrm{t}_{\text {hitung }}$ $=2,21$ dan $t_{\text {tabel }}=2,09$ karena $t_{\text {hitung }}>\mathrm{t}_{\text {tabel }}$ maka $\mathrm{H}_{0}$ ditolak dan $\mathrm{H}_{1}$ diterima artinya bahwa data berdistribusi normal, dengan demikian model pembelajaran berbasis masalah berpengaruh terhadap kemampuan berpikir kritis matematis siswa.
\end{abstract}

Kata kunci : Model Pembelajaran berbasis masalah, kemampuan berpikir kritis matematis siswa.

\section{PENDAHULUAN}

Pendidikan bukan hanya sekedar media untuk mewariskan kebudayaan kepada generasi selanjutnya, tetapi dengan pendidikan diharapkan mampu merubah dan mengembangkan pola kehidupan bangsa ke arah yang lebih baik. Tujuan pendidikan di Indonesia adalah terwujudnya sumber daya manusia yang berkualitas, yang 
mampu menghadapi tantangan hidup dalam dunia yang makin kompetitif, serta dapat memilih dan mengolah informasi untuk digunakan dalam mengambil keputusan sekaligus mampu menyesuaikan diri dengan perubahan-perubahan yang mungkin terjadi di lingkungan sekitarnya.

Undang-Undang Nomor 20 Tahun 2003 tentang Sistem Pendidikan Nasional menyatakan bahwa pendidikan adalah usaha sadar dan terencana untuk mewujudkan suasana belajar dan proses pembelajaran agar siswa secara aktif mengembangkan potensi dirinya untuk memiliki kekuatan spiritual keagamaan, pengendalian diri, kepribadian kecerdasan, akhlak mulia, serta ketrampilan yang diperlukan dirinya, masyarakat dan negara. Oleh karena itu, pendidikan yang dilaksanakan seharusnya mampu mencetak lulusan yang berkualitas dan memiliki daya saing yang tinggi dengan negara lain. Namun, dengan pesatnya perkembangan zaman selalu memunculkan tantangan-tantangan baru, yang sering tidak diramalkan sebelumnya sebagai konsekuensi logis pendidikan yang selalu dihadapkan pada masalah-masalah baru.

Upaya meningkatkan kualitas pendidikan di Indonesia dilakukan secara berkesinambungan dan sampai saat ini terus dilaksanakan, sebab dalam konteks reformasi pendidikan wajib hukumnya, karena pendidikan sebagai salah satu usaha sadar untuk meningkatkan kualitas kepribadian dan kemampuan seorang guru, yang perlu dikembangkan sesuai dengan tujuan dan arah pembanguan nasional. Sehubungan dengan fungsi dan tujuan pendidikan yang demikian penting yang perlu dikembangkan, guru dalam konteks pendidikan mempunyai peran besar dan strategis, hal ini disebabkan gurulah yang berada dibarisan terdepan dalam pelaksanaan pendidikan, gurulah yang mentransfer ilmu pengetahuan dan teknologi sekaligus mendidik dengan nilai-nilai positif melalui bimbingan dan keteladanan sebagaimana yang diharapkan (Kunandar, 2008: 20).

Berpikir juga merupakan suatu kegiatan mental untuk membangun dan memperoleh pengetahuan. Dalam suatu proses pembelajaran, kemampuan berpikir 
peserta didik dapat dikembangkan dengan memperkaya pengalaman yang bermakna melalui persoalan pemecahan masalah. Salah satu kemampuan berpikir yang termasuk ke dalam kemampuan berpikir tingkat tinggi adalah kemampuan berpikir kritis matematis.

Berpikir kritis merupakan pengujian rasional terhadap ide, pengaruh, asumsi, prinsip, argumen, kesimpulan, isu, pernyataan, keyakinan, dan aktivitas, (Deswani, 2009: 119). Penggunaan model pembelajaran sangat mempengaruhi cara berpikir kritis siswa pada materi yang diajarkan guru dalam proses belajar mengajar, sebab model pembelajaran yang digunakan dalam kegiatan pembelajaran dapat membantu guru menghasilkan materi pembelajaran dengan situasi dunia nyata siswa yang menekankan pada proses penyelesaian masalah yang dihadapi siswa secara ilmiah dan mendorong siswa untuk membuat hubungan antara pengetahuan yang dimiliki dan penerapannya yang dilakukan dalam kehidupan sehari-hari.

Berdasarkan hasil studi awal di SMP Negeri 62 Halmahera Selatan, ternyata yang sering ditemui selama ini yakni guru pada umumnya masih berpegang pada kebiasaan mengajar secara konvensional, yaitu guru mengajar dengan metode ceramah pada awal pembelajaran, menerangkan materi dan memberi soal, sedangkan aktivitas siswa hanya mendengarkan dan mengerjakan soal saja dan kemudian guru menjelaskan kembali tentang hal yang belum dikuasai oleh siswa.

Diakui atau tidak ini merupakan cara yang tidak efektif yang dilakukan oleh guru, Sehingga berpikir kritis matematis siswa menjadi menurun. Ironisnya sebagian besar siswa selalu meganggap bahwa matematika adalah pelajaran yang sulit yang kemudian membuat siswa bosan dalam belajar,untuk memahami konsep matematika yang dirasakan sulit dibutuhkan motivasi dan keaktifan dari siswa. 


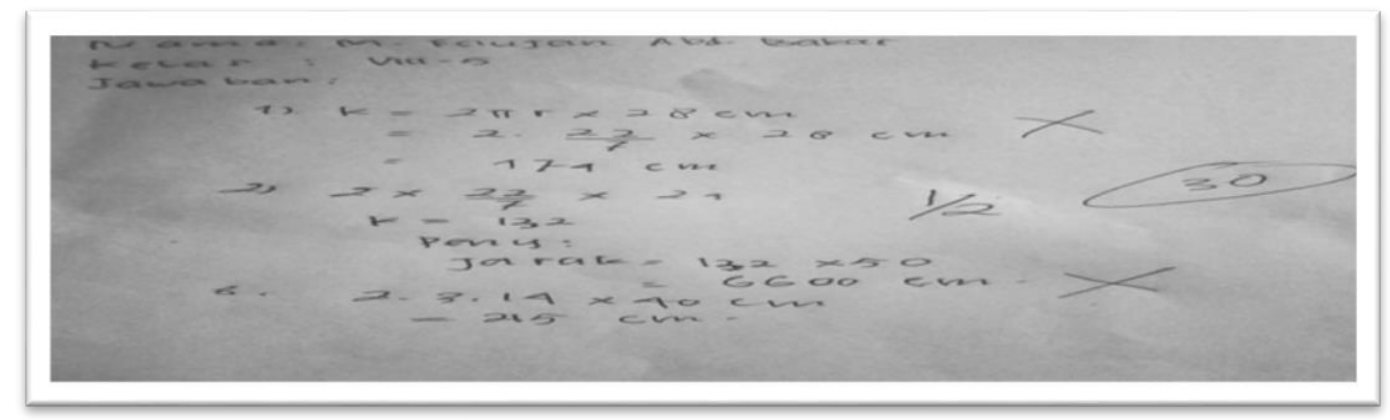

Gambar 1

Salah satu hasil kerja siswa dalam menyelesaikan soal pada materi lingkaran.

Berdasarkan gambar hasil kerja siswa di atas, terlihat bahwa siswa belum bisa menentukan keliling lingkaran, kemudian siswa belum bisa menetukan keliling dan jarak lingkaran namun jawabannya sudah benar, dan juga belum bisa menentukan panjang pita yang terdapat pada soal tersebut. Bersandar pada alasan yang dikemukakan di atas, jelaslah bahwa kemampuan berpikir kritis matematis siswa sangat penting untuk dikembangkan. Oleh karena itu guru hendaknya mengkaji dan memperbaiki kembali praktik-praktik pengajaran yang selama ini dilaksanakan yang mungkin hanya sekadar rutinitas belaka. Menyadari pentingnya suatu sistem pembelajaran untuk mengembangkan kemampuan berpikir kritis matematis siswa, maka mutlak diperlukan adanya pembelajaran matematika yang lebih banyak melibatkan siswa secara aktif dalam proses pembelajaran itu sendiri. Hal ini dapat terwujud melalui suatu bentuk sistem keterlibatan siswa secara aktif yang menanamkan kesadaran berpikir kritis matematis siswa.

Kunandar, (2007: 35) menyatakan bahwa pembelajaran berbasis masalah adalah suatu model pembelajaran yang menggunakan masalah dunia nyata sebagai suatu konteks bagi siswa untuk belajar tentang cara berpikir dan keterampilan penyelesaian masalah serta untuk memperoleh pengetahuan dan konsep yang esensial dari mata pelajaran.

Model Pembelajaran berdasarkan masalah menurut Dewey (Trianto, 2009: 91) belajar berdasarkan masalah adalah interaksi antara stimulus dan respon merupakan 
hubungan antara dua arah belajar dan lingkungan. Lingkungan memberikan masukan kepada siswa berupa bantuan dan masalah, sedangkan sistem saraf otak berfungsi menafsirkan bantuan itu secara efektif sehingga masalah yang dihadapi dapat diselidiki, dinilai, dianalisis, serta dicari pemecahannya dengan baik.

Pembelajaran berdasarkan masalah merupakan pendekatan yang efektif untuk pengajaran proses berpikir tingkat tinggi. Pembelajaran ini membantu siswa untuk memproses informasi yang sudah jadi dalam benaknya dan menyusun pengetahuan sendiri tentang dunia sosial dan sekitarnya. Pembelajaran ini cocok untuk pengetahuan dasar maupun kompleks. Pembelajaran berbasis masalah juga dilandasi teori konstruktivis, pada pembelajaran ini dimulai dengan menyajikan masalah nyata yang penyelesaiannya membutuhkan kerjasama antar siswa, guru memandu siswa menguraikan rencana pemecahan masalahmenjadi tahap-tahap kegiatan, guru memberi contoh mengenai penggunaan ketrampilan dan strategi yang dibutuhkan supaya tugas-tugas tersebut dibutuhkan dapat diselesaikan. Guru menciptakan suasana kelas yang fleksibel dan berorientasi pada upaya penyelidikan oleh siswa.

\section{METODE PENELITIAN}

Penelitian ini adalah jenis penelitian kualitatif dan akan menggunakan desain penelitian pra-eksperimental, karena penelitianya berbeda antara pretest dan posttes. Menurut Sugiyono (2014: 74), desain pra - eksperimen tidak benar-benar dianggap sebagai hasil percobaan karena ada variabel luar yang berlaku pada pembentukan variabel dependen. Peneliti menggunakan desain pra - eksperimen dengan pretest satu kelompok dan desain posttest. Dalam hal ini desain penelitianya adalah sebagai berikut:

Tabel 2

Desain Penelitian pretest-posstes
\begin{tabular}{|r|r|r|}
\hline $\mathrm{O}_{1}$ & $\mathrm{X}$ & $\mathrm{O}_{2}$ \\
\hline
\end{tabular}

Ketetarangan:

$\mathrm{O}_{1} \quad$ Pretest (sebelum penerapan model pembelajaran berbasis masalah) 
$\mathrm{X} \quad$ : Penerapan model pembelajaran berbasis masalah)

$\mathrm{O}_{2} \quad$ : Posttest (sesudah penerapan model pembelajaran berbasis masalah)

Variabel dalam penelitian ini adalah sebagai berikut:

1. Variabel Terikat

Variabel terikat dalam penelitian ini adalah kemampuan berpikir kritis matematis siswa.

2. Variabel Bebas

Variabel bebas dalam penelitian ini adalah model pembelajaran, yaitu model pembelajaran berbasis masalah.

Untuk mengetahui kemampuan berpikir kritis matematis siswa pada materi kubus, peneliti menggunakan acuan Kriteria kemampuan berpikir kritis kelas VIII SMP Negeri 62 Halmahera selatan dengan kriteria sebagai berikut:

Tabel 4.

Nilai kriteria kemampuan berpikir kritis kelas VIII SMP Negeri 62 Halmahera Selatan

\begin{tabular}{|c|c|c|}
\hline No & Rentang Skor & $\begin{array}{c}\text { Tingkat Berpikir } \\
\text { Kritis }\end{array}$ \\
\hline 1 & $80-100$ & Sangat kritis \\
\hline 2 & $60-79$ & Kritis \\
\hline 3 & $40-59$ & Cukup kritis \\
\hline 4 & $0-39$ & Kurang kritis \\
\hline
\end{tabular}

Proses analisis data menggunakan langkah-langkah seperti di bawah ini.

Menghitung presentase dari skor yang dicapai setiap siswa dalam menyelesaikan soal dengan menggunakan rumus:

$$
P=\frac{\text { skor rata-rata }}{\text { Skor maksimal }} \times 100 \%
$$

Keterangan : $\mathrm{P}=$ Persentasi kemampuan berpikir kritis matematis

$\mathrm{f}=$ Sekor rata-rata

$\mathrm{N}=$ Sekor maksimal. 


\section{HASIL DAN PEMBAHASAN}

\section{A. HASIL}

Data hasil tes awal menunjukkan bahwa rata-rata kemampuan berpikir kritis matematis siswa dari nilai tes awal siswa pada kelas VIII-1 adalah 43,74 dan jumlah siswa yang mencapai Kriteria kemampuan berpikir kritis adalah 0 siswa. Kemudian hasil tes akhir menunjukan bahwa rata-rata dari nilai tes akhir pada ke las VIII-1 adalah 82,5, dan jumlah siswa yang mencapai Kriteria adalah 12 siswa.

\section{Pembelajaran Berbasis Masalah berpengaruh terhadap kemampuan berpikir kritis matematis siswa dijawab dengan menggunakan langkah- langkah sebagai berikut.}

\section{1) Pengujian Persyaratan Analisis}

Data yang digunakan pada analisis statistik inferensial ini adalah data yang diperoleh dari satu kelas setelah perlakuan. Data setelah perlakuan digunakan untuk melakukan pengujian hipotesis, yaitu mengetahui bagaimana kemampun berpikir kritis matematis siswa setelah diterapkannya model pembelajaran berbasis masalah, dan pengaruh model pembelajaran berbasis masalah terhadap kemampuan berpikir kritis matematis siswa. Selanjutnya dilakukan uji normalitas untuk mengetahui apakah data berasal dari populasi yang berdistribusi normal atau tidak normal.

\section{2) Pengujian normalitas}

\section{Tabel 2.}

Uji normalitas data

\begin{tabular}{|c|c|c|}
\hline \multicolumn{3}{|c|}{ Pembelajaran berbasis masalah } \\
\hline$\chi_{\text {hit }}^{2}$ & $\chi_{\text {tab }}^{2}$ & Kesimpulan \\
\hline$-12,61$ & 2,09 & Normal \\
\hline
\end{tabular}


Hasil uji normalitas data untuk siswa kelas eksperimen dengan rumus chikuadrat diperoleh nilai $x^{2}$ hitung $=-12,61$ dan $x_{\text {tabel }}^{2}=2,09$ karena $x^{2}$ hitung $\leq x_{\text {tabel }}^{2}$ maka kesimpulannya data berdistribusi normal, (Analisis data selengkapnya dapat dilihat pada lampiran 15 halaman 97-99).

\section{Pengujian hipotesis}

Berdasarkan uji chi kuadrat menunjukan bahwa data tentang hasil belajar siswa setelah diajarkan dengan model pembelajaran berbasis masalah berdistribusi normal. Sehingga statistik uji yang digunakan adalah statistik uji parametrik yakni uji t.

Tabel 3.

Uji hipotesis

\begin{tabular}{|c|c|c|}
\hline \multicolumn{3}{|c|}{ Uji hipotesis } \\
\hline $\mathrm{t}_{\text {hitung }}$ & $\mathrm{t}$ tabel & Kesimpulan \\
\hline 2,21 & 2,09 & $\mu_{1}>\mu_{0}$ \\
\hline
\end{tabular}

Hasil uji t untuk mengetahui tingkat kemampuan berpikir kritis matematis siswa dengan model pembelajaran berbasis masalah diperoleh $t_{\text {hitung }}=2,21$ dengan $t_{\text {tabel }}=$ 2,09 maka $t_{\text {hitung }} \geq t_{\text {tabel }}$ atau 2,21 $\geq 2,09$ dengan taraf signifikan $(\alpha)=0,05$. Maka $\mathrm{H}_{0}$ di tolak dan $\mathrm{H}_{1}$ diterima artinya bahwa data berdistribusi normal dengan demikian model pembelajaran berbasis masalah berpengaruh terhadap kemampuan berpikir kritis matematis siswa.

\section{B. PEMBAHASAN}

Berdasarkan analisis dan penyajian data di atas diketahui tingkat kemampuan berpikir kritis matematis siswa sesudah proses pembelajaran dengan menerapkan model pembelajaran berbasis masalah. Pada penelitian ini, dilakukan hanya pada 1 kelas yaitu kelas VIII-1 yang terindikasi rendahnya kemampuan berpikir kritis matematis. Tujuan dilakukan penelitian ini adalah untuk melihat dan mengetahui kemampuan berpikir kritis matematis siswa setelah diterapkannya model pembelajaran berbasis masalah, Berikut pembahasan dari hasil penelitian: 


\section{Kemampuan berpikir kritis Matematis Siswa Setelah diterapkan Model Pembelajaran berbasis masalah.}

Berdasarkan hasil penelitian, diperoleh kemampuan berpikir kritis matematis siswa setelah diterapkan model pembelajran berbasis masalah diperoleh kualifikasi kritis dan kurang kritis yang dianilisis dengan kriteria kemampuan berpikir kritis matematis, Berikut disajikan hasil posttest siswa yakni tes sesudah pembelajaran berbasis masalah untuk setiap kualifikasi dan pembahasannya.

\section{a. Disajikan hasil posttest siswa dengan kualifikasi kritis.}

1. Berikut ini hasil pekerjaan siswa dalam menyelesaikan tes akhir kemampuan berpikir kritis matematis siswa berdasarkan indicator. Siswa yang berpikir kritis pada kemampuan menganalisis yaitu kemampuan menentukan informasi dari soal yang diberikan dan bisa memilih informasi yang penting dan memilih strategi yang benar dalam menyelesaikannya, dan benar melakukan perhitungan. Hasil pekerjaan siswa pada gambar di bawah ini:

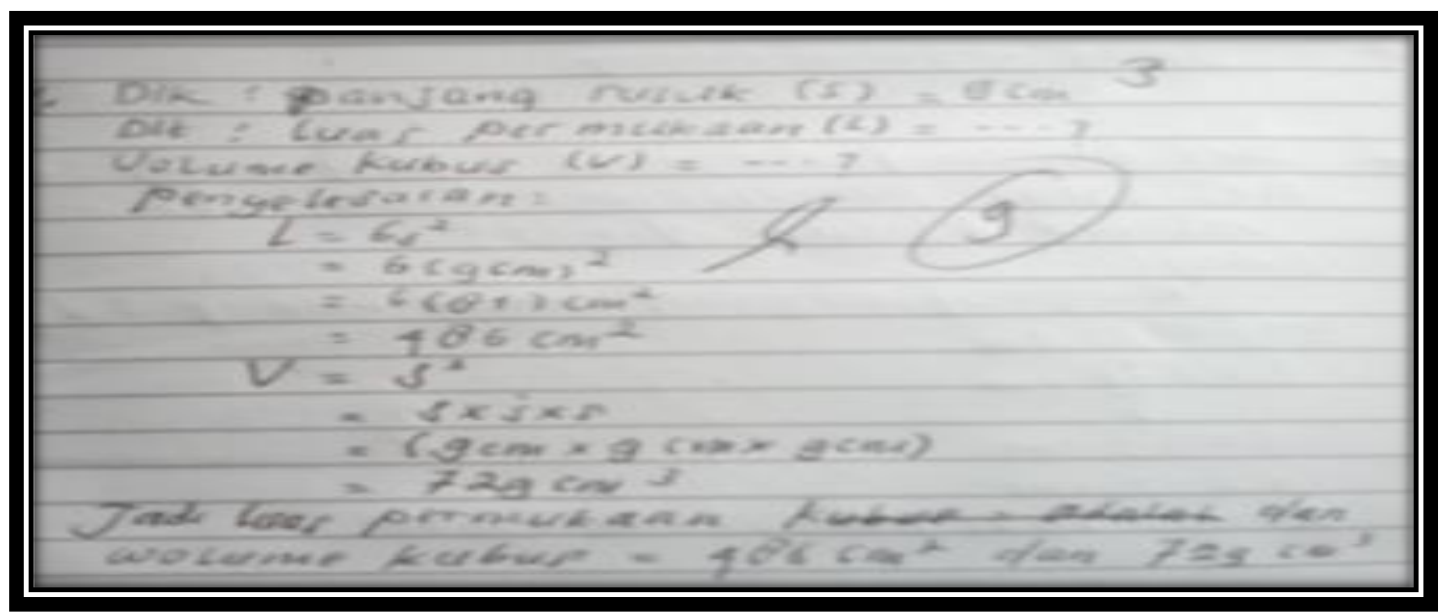

Gambar 1.

Hasil posttst siswa F1 yang berkualifikasi kritis. 
Hasil pekerjaan siswa pada gambar satu di atas dapat dlilihat bahwa siswa sudah menjawab dengan benar. Siswa sudah mampu dalam menentukan diketahui panjang rusuk kubus $(\mathrm{s})=9 \mathrm{~cm}$ dan ditanya luas permukaan kubus dengan penyelesaian yang benar dari soal yang diberikan kemudian bisa memilih strategi, juga benar melakukan perhitungan.

2. Berikut ini adalah hasil pekerjaan siswa yang berkualifikasi kritis pada kemampuan memberikan penjelasan sederhana artinya mengidentifikasi atau merumuskan permasalahan ke dalam model matematika. Hasil pekerjaan siswa pada gambar di bawah ini:

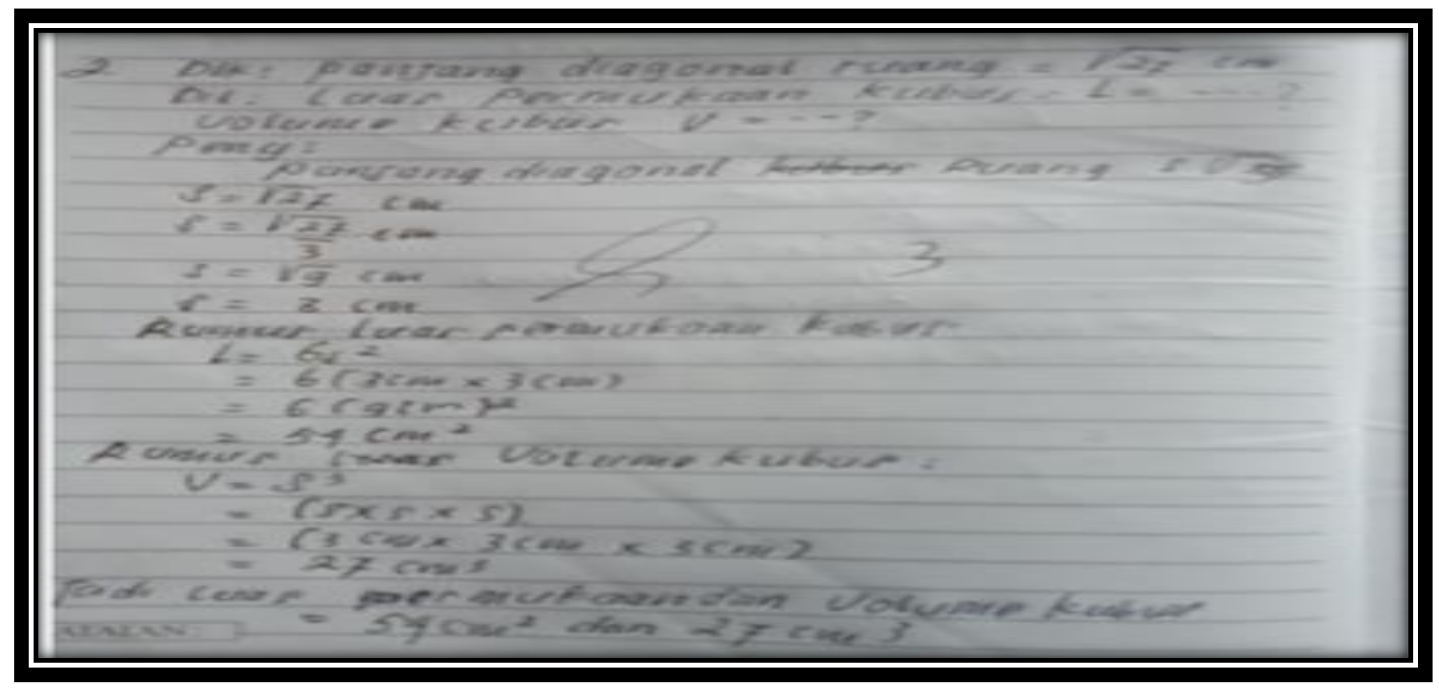

\section{Gambar 2.}

Hasil posttest siswa F1 yang berkualifikasi kritis.

Hasil pekerjaan siswa pada gambar ke dua di atas menunjukan bahwa siswa sudah mampu merumuskan permasalahan ke dalam model matematika, artinya bahwa siswa sudah bisa menentukan rumus untuk panjang diagonal ruang, rumus untuk luas permukaan kubus, rumus untuk volume kubus yang sudah sesuai dengan penyelesaian yang diharapkan, sehingga diberikan skor 3. 
3. Berikut ini adalah Siswa yang berkualifikasi kritis pada kemampuan membangun keterampilan dasar yaitu menggunakan prosedur langkah penyelsaian yang tepat, gambar salah satu hasil pekerjaan siswa yang berkualifikasi baik di bawah ini.

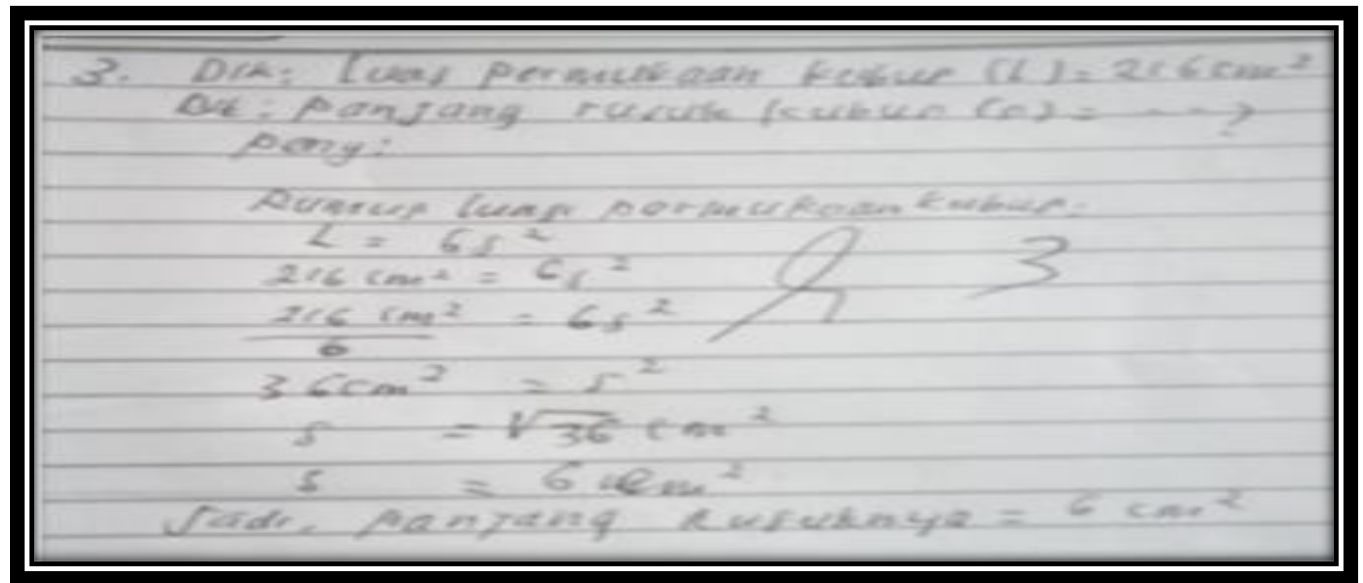

Gambar 3.

Hasil posttest siswa F1 yang berkualifikasi kritis.

Hasil pekerjaan siswa pada gambar tiga di atas menunjukan bahwa siswa sudah mampu menjawab soal dengan prosedur langkah penyelesaian yang tepat dengan jawaban akhir yang benar, dan sesuai dengan apa yang diharapakn sehingga diberikan skor 3.

\section{b. Disajikan hasil posttest siswa dengan kualifikasi kurang kritis.}

1. Siswa yang berkualifikasi kurang kritis pada kemampuan menganalisis adalah kemampuan menentukan informasi dari soal yang diberikan dan bisa memilih informasi yang penting dan memilih strategi yang benar dalam menyelesaikannya, dan benar melakukan perhitungan, Gambar hasil pekerjaan siswa di bawah ini:

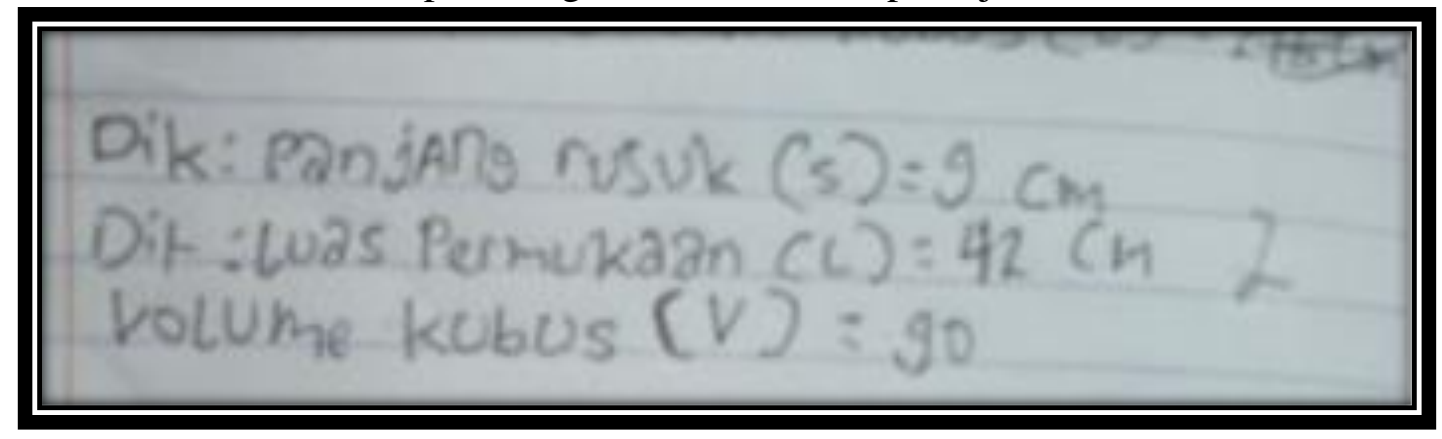




\section{Gambar 4}

Salah satu hasil posttest siswa F4 kualifikasi kurang kritis.

Hasil pekerjaan siswa pada gambar 4 di atas menunjukan bahwa siswa sudah bisa menentukan informasi diketahui panjang rusuk kubus (s) $=9 \mathrm{~cm}$ dan ditanya luas permukaan dan volume kubus yang terdapat pada soal, namun belum mampu melakukan perhitungan dengan benar dan masih mengandung sedikit kesalahan sehingga diberikan skor 2 .

2. Siswa yang berkualifikasi kurang kritis pada kemampuan memberikan penjelasan sederhana artinya mengidentifikasi atau merumuskan permasalahaan ke dalam model matematika, di bawah ini merupakan Gambar salah satu hasil pekerjaan siswa kualifikasi kurang kritis.

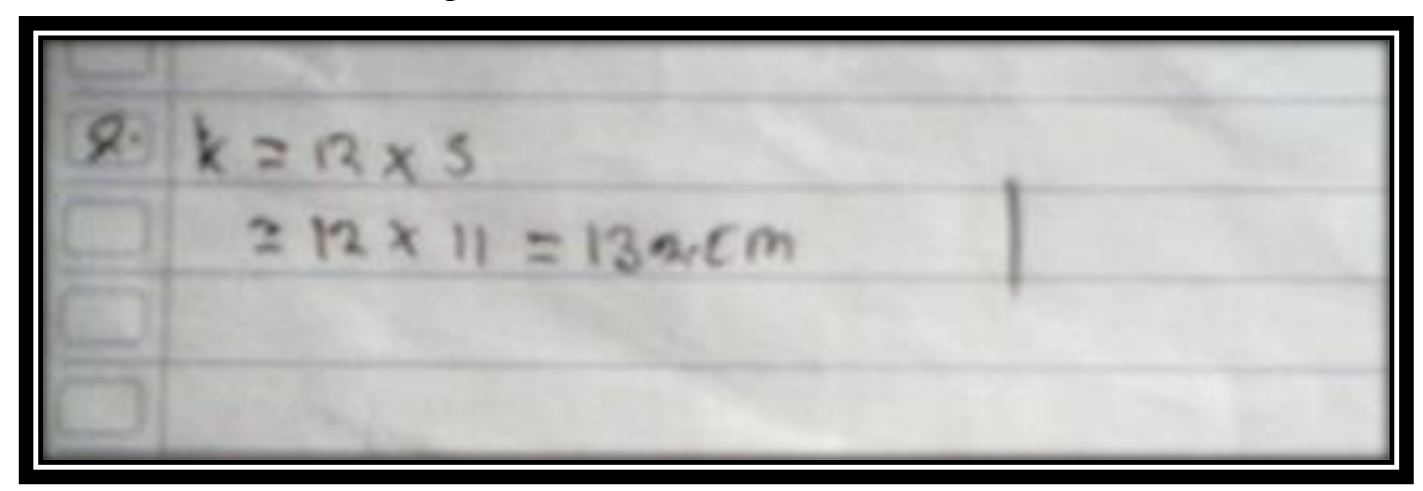

\section{Gambar 5.}

Hasil pekerjaan siswa F2 berkualifikasi kurang kritis.

Hasil pekerjaan siswa pada gambar 5 di atas menunjukan bahwa siswa hanya menuliskan jawabannya secara langsung namun masih keliru, dan juga belum bisa mengidentifikasi permasalahan ke dalam model matematika sesuai dengan indikator sehingga diberikan skor 1.

3. Siswa yang berkualifikasi kurang kritis pada kemampuan membangun keterampilan dasar adalah menggunakan prosedur langkah penyelsaian yang tepat, di bawah ini merupakan Gambar salah satu hasil pekerjaan siswa kualifikasi kurang kritis. 


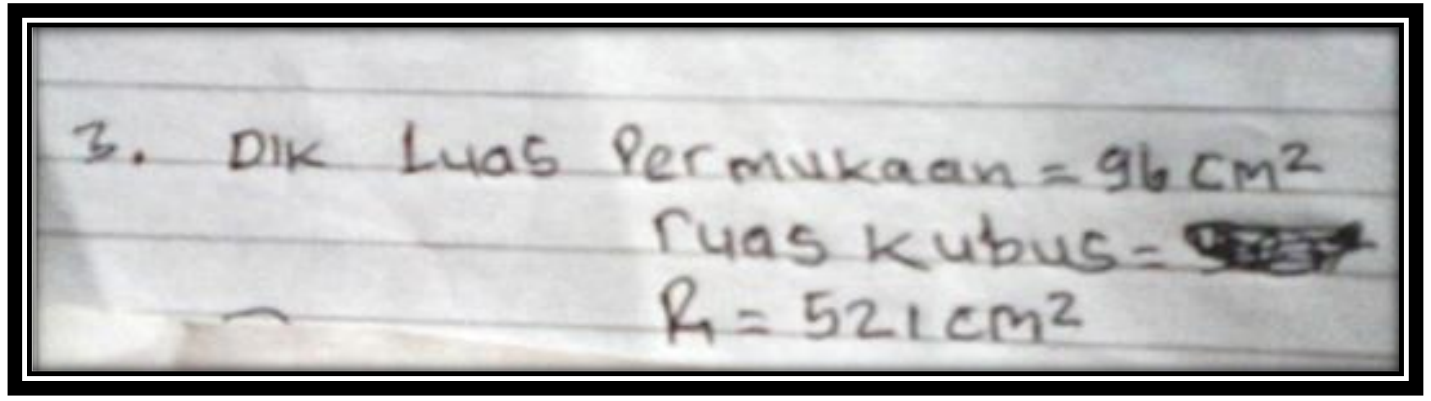

\section{Gambar 6.}

Hasil posttest siswa F4 berkualifikasi kurang kritis.

Hasil pekerjaan siswa pada gambar 6 di atas menunjukan bahwa siswa sudah menuliskan jawabannya namun belum sesuai dengan indikator yakni belum menggunakan prosedur langkah penyelesaian yang tepat sehingga diberikan skor 1 .

\section{Pembelajaran Berbasis Masalah berpengaruh terhadap kemampuan berpikir kritis matematis siswa.}

Berdasarkan analisis data hasil belajar siswa dan pengamatan peneliti dalam kegiatan belajar mengajar di kelas, bahwa model pembelajaran berbasis masalah berpengaruh terhadap kemampuan berpikir kritis matematis siswa. Hal ini disebabkan beberapa faktor yang mempengaruhinya, yaitu sebagai berikut:

Dalam Pembelajaran Matematika dengan menggunakan model PBM, siswa dikelompokkan ke dalam beberapa kelompok, siswa lebih siap dalam menerima materi yang diberikan, diberi ruang untuk bekerja sama dalam kelompok, dilibatkan secara aktif untuk memecahkan masalah yang telah diberikan oleh peneliti secara bersama-sama. Dalam menyelesaikan masalah tersebut siswa dirangsang untuk belajar secara mandiri dan bekerja sama untuk menyelesaikan masalah yang telah diberikan oleh peneliti, sehingga apabila ada siswa yang belum paham dalam menyelesaikan masalah maka bisa dijelaskan oleh teman-teman lain dalam satu kelompok. Hal ini membuat siswa aktif dalam kegiatan belajar mengajar.

Pada Pembelajaran Matematika dengan menggunakan model PBM, siswa diberi kebebasan untuk mengembangkan strategi dalam menyelesaikan masalah sehingga 
siswa dapat memperoleh strategi yang bervariasi. Hal ini membuat siswa tidak ragu dalam menyelesaikan permasalahan atau soal yang diberikan. Model pembelajaran Berbasis masalah dilaksanakan melalui beberapa tahap dalam proses pembelajaran, langkah yang pertama guru (peneliti) membentuk kelompok-kelompok belajar siswa yang heterogen dan setiap kelompok terdiri dari 4-5 siswa, hal ini dimaksud agar pada proses diskusi tidak hanya sebagian kelompok yang aktif. Selanjutnya peneliti membagikan bahan bacaan yang berisikan materi tentang kubus, pada langkah ini siswa dituntut untuk aktif dalam diskusi kelompok guna saling membantu dalam memahami materi kubus dan mengerjakan LKS yang diberikan oleh guru (peneliti), kemudian Pada tahap ini juga guru (peneliti) mengawasi jalannya diskusi. Setelah itu, guru (peneliti) meminta perwakilan kelompok tertentu untuk mempresentasikan hasil diskusinya di depan kelas. Selanjutnya guru (peneliti) merangkum kembali hasil kerja siswa, agar siswa dalam kelompok tersebut dapat mengetahui kesalahan-kesalahan dalam mengerjakan soal yang ada pada LKS dan siswa juga dapat mengerti materi tentang kubus. Setelah guru (peneliti) menjelaskan kembali soal yang ada pada LKS, siswa dapat kembali ke tempat duduk masing-masing dan membuat kesimpulan terkait dengan konsep yang diajarkan. (peneliti) dapat mengetahui kemampuan berpikir kritits matematis siswa pada materi kubus untuk masing-masing siswa setelah bekerja sama dalam kelompok.

\section{KESIMPULAN}

Berdasarkan hasil penelitian dan pembahasan dapat disimpulkan sebagai berikut:

1. Kemampuan berpikir kritis matematis siswa setelah diterapkan model pembelajaran berbasis masalah diperoleh 12 siswa (60\%) yang sudah berpikir kritis dan 8 siswa (40\%) yang berpikir kritisnya kurang.

2. Model pembelajaran berbasis masalah berpengaruh terhadap kemampuan berpikir kritis matematis siswa kelas VIII-1 SMP Negeri 62 Halmahera Selatan. 


\section{DAFTAR PUSTAKA}

Departemen Pendidikan Nasional, 2003.Undang-Undang Nomor 20 Tahun 2003, Tentang Sistem Pendidikan Nasional, Jakarta: Depdiknas.

Deswani. 2009. Proses Keperawatan dan Berpikir Kritis. Jakarta: Salemba Medika.

Kunandar. 2007.Guru Profesional (Implementasi Kurikulum Tingkat Pendidikan (KTSP) dan Sukses dalam Sertifikasi Guru). Jakarta: Rajal J Persada.

Kunandar. 2008..Langkah Mudah Penelitian Tindakan Kelas Sebagai Pengembangan Profesi Guru. Jakarta:Raja Grafindo Persada.

Sugiyono. (2014) Metode penelitiaan kuantitatif kualitatif dan R\&D. CV Alfabeta.

Trianto. 2009. Mendesain model Pembelajaran Model Inovatif Progresif. Jakarta: Kencana Prenada Group. 